\title{
Researching and Practicing of Researching Teaching Mode in the Curriculum of Mechanical Manufacture Technology
}

\author{
Xuming Ye, Shukui Wang \\ School of Mechanical Engineering, Shenyang University, Shenyang 110044, China
}

Keywords: investigation; teaching; method; practice.

\begin{abstract}
The research teaching Mode is explored and interpreted on its definition and system composition, setting topic, role changing of teacher and evaluation index of academic records, basing on the research teaching in curriculum of mechanical manufacture technology.
\end{abstract}

\section{《机械制造技术》课研究性教学法研究与实践}

\author{
叶旭明 王树逵 \\ （沈阳大学 机械工程学院 辽宁 沈阳 110044）
}

关键词：研究性,教学,方法,实践。

【摘要】：本文结合作者在专业课教学中采用的研究性教学法, 对研究性教学法的定义、体 系构成、研究性课题的拟订、教师角色的转变、学生研究性学习成绩评价指标等问题进行了 探索和介绍。

\section{1. 背景分析}

目前, 在课堂理论教学中, 尽管任课教师采用了各种各样的教学方法, 但基本上是以教师 为主体, 处于 “满堂灌” 状态; 而课程的结业成绩以期末考试为主, 学生考前突击、死记硬 背、考后清零; 由于教师的教学方法和学生学习方法的限制, 导致了学生考试及格了, 但成 绩与能力不对等, 不能做到学以至用。

针对上述问题, 如何在专业课的教学中, 任课教师采用新的教学方法, 使学生能够成为课 堂的主体, 教师成为主导, 就显得尤为重要。

\section{2. 研究性教学法简介}

研究性教学法是以学生的自主性、探索性学习为基础, 从学生所学课程中选择和确定研究 专题, 以个人或小组合作方式进行学习的教学方法。该方法立足于改变学生的学习方式, 强 调一种主动探究式的学习, 与传统的教学方法相比有着很大的差异。

结合《机械制造技术》课程, 研究性教学法总体设计的指导思想是: “以零件为主线, 将 课堂教学、实践性教学环节、考核穿成串; 以研究性教学方法为手段, 将期末考核改为过程、 能力考核; 从而达到强化学生分析解决问题能力培养之目的”。

所谓以零件为主线, 是指任课教师在课程开始前, 给每名学生发一个零件图, 这张图将伴 随着学生整个课程直至课程设计的学习。课堂理论教学在时间段上分成三大部分, 一是任课 教师根据课程的特点、任务、应该掌握的知识点、教学要求等进行的概述; 二是由学生讲述 的研究课题; 其三是任课教师根据学生对知识点的掌握和讲述情况, 所进行的课堂指导。 


\section{3. 采用研究性教学法的条件}

针对《机械制造技术》课程, 采用研究性教学法的前提条件是首先要建立两个 “库”, 二 是考试方式的改革, 三是开放的实验教学条件。

两个 “库” 是指 “零件库”和 “研究性课题库”。

考试方式的改革是将期末考试改为过程、能力考核。

\section{1零件库的建立}

从机械加工企业中收集与课程教学要求密切相关的零件建 “库”。零件的机械加工大约需 要10道工序, 并适合作为《机械制造技术》课程 “机械加工工艺规程及专用夹具设计” 课程 设计用图。

零件以图纸的形式发给学生, 并要求学生利用CAD将零件绘制成电子文档, 以锻炼学生利 用 CAD软件的绘图能力。

\section{2研究性课题库的建立}

在项目实施前, 教学团队要根据课程教学大纲要求, 设计研究性课题。对研究性课题要求 有:

(1) 课题名称;

（2）课题应涵盖的知识点和基本概念;

(3) 结合具体零件的实例;

(4) 结论。

例如，针对 “机床夹具的定位原理”一节，可以设计 “工件是如何在机床上定位的” 这样 一个研究性课题, 对该课题的具体要求有：六点定位原理、关于定位的基本概念、在定位过 程中容易出现的问题、结合具体零件定位方案的选择、定位误差分析计算等。以上这些要求, 随同课题题签一同发给学生。

\section{3考试方式的改革}

实施研究性教学法, 将取消课程的期末考试, 将期末考试变革为教学过程、学生能力考核。 学生的课程结业成绩考核依据主要有以下几个方面。

(1) 学生的研究性课题成果

学生要将研究性课题的研究成果制作成电子文档, 作为成绩考核依据内容之一。

(2) 学生评价

每名学生将自己要介绍的研究性课题制作成PPT, 在课堂上进行讲述。在整个课程学习中, 每名学生大约要进行两次。其他学生对讲述研究成果的学生进行打分, 此成绩作为成绩考核 依据之一。

（3）教师评价

教师要对学生的研究性课题讲述、电子文档、PPT制作等方面进行评价打分, 此成绩作为 课程结业考核依据之一。

(4) 作业

因为每名学生一个不同的零件，根据零件完成的作业具有针对性且不雷同，作业成绩也作 为期末结业成绩考核依据之一。

(5) 口试

在课程结业时, 对学生进行口试。口试题目均来自其他学生宣讲的研究性课题, 此成绩 亦为结业成绩考核依据之一。

各项成绩考核点占学生课程结业成绩的比例，在教师进行课程概述时应予以明确。

在这个过程中, 也锻炼了学生办公自动化手段和方法的应用能力。

\section{4 实验教学条件}

开发的实验教学条件, 也是研究性教学法实施的条件之一。结合教学内容, 学生可以利用 现有的实验条件, 自行设计实验项目，从而锻炼动手能力。 


\section{4. 研究性教学中教师角色的转变}

研究性教学法的采用, 要求教师从知识的传授者到学生课题研究的参与者; 学生学习的促 进者、组织者、指导者。教师不仅仅关注教科书, 更要关注本学科知识与实践的联系, 本学 科的前沿知识、相关学科的联系; 从单纯的知识传授到关心学生的终身发展等等。教师的角 色和以往不同, 要求发生较大的变化。概括起来, 教师在研究性教学中, 将成为:

\section{1学生学习的参与者}

教师以平等的身份主动参与学生的课题研究。作为参与者, 教师要经常深入学生课题组的 活动, 了解倾听学生的需求, 拉近教师和学生的距离, 大胆地发表自己的意见。教师在课题 的参与中, 可以随时掌握学生的问题, 有的放矢地进行指导。同时也正是在参与中, 教师也 可以从中学到新东西, 在参与中学习, 在学习中指导。

\section{2学生学习的指导者}

教师是学生学习的指导者, 而这里的指导与以往教学中的指导有很大不同。以往指导主要 是找出学生问题所在, 然后通过解惑、解难, 最后把学生引导到教师心目中早已有的标准答 案上来。但研究性教学中, 学生研究的课题各不相同, 教师对学生课题最后得到的答案事先 并不很明确, 因此所谓的 “标准答案” 事实上已不复存在。在研究性教学中, 教师指导的作 用大体归纳为：研究思路的指导、研究方法的指导和信息资料来源的指导。这种指导要求教 师一方面能抓住学生思想的火花, 输送氧气, 让它能燃烧起来; 另一方面则是运用老师的知 识积淀、经验和智慧, 给学生一些点拨和启发, 即所谓的 “点到为止” , 将思考和想象的空 间留给学生。

\section{3学生学习的组织者和促进者}

研究性教学中学生的活动有时是分散的、自主管理的。由于学生自控能力的差异会导致活 动的管理组织和活动质量有较大的不同, 这就需要教师在指导学生的同时, 还要做好学生学 习的组织工作，帮助学生克服困难、树立信心、保持旺盛的求知欲和持之以恒的积极性等。

教师上述角色的变化, 反映了时代对教师的新要求。一个只会把教科书的内容搬到学生头 脑中的教师显然已经落伍。以研究性教学为开端, 教师将从思想观念、知识结构、工作方式 和行为方式等方面挑战自己、改变自己和完善自己。从这个意义上说, 研究性教学法是提升 教师素质的一个良好手段。

\section{5. 结语}

研究性教学法作为一种新的教学方法, 还需要在教学实践中不断总结和完善, 在理论方面 加以升华。其中的选题指导策略方法、考核体系的量化、学生学习方式转变带来的相关问题、 教学法与课程改革的关系等, 还需要进一步的探索。

\section{Reference}

[1] Zhang Shuyu. Modern Educational Technology. Anhui peoples Publishing House, 2003.

[2] Zhang Daifu. The whole guidance of research study. Wuhan Press, 2003.

[3] Su Fei , Huang Xiuyi. The hundreds of case of research study integrated science. Guangxi Normal University Press, 2003. 